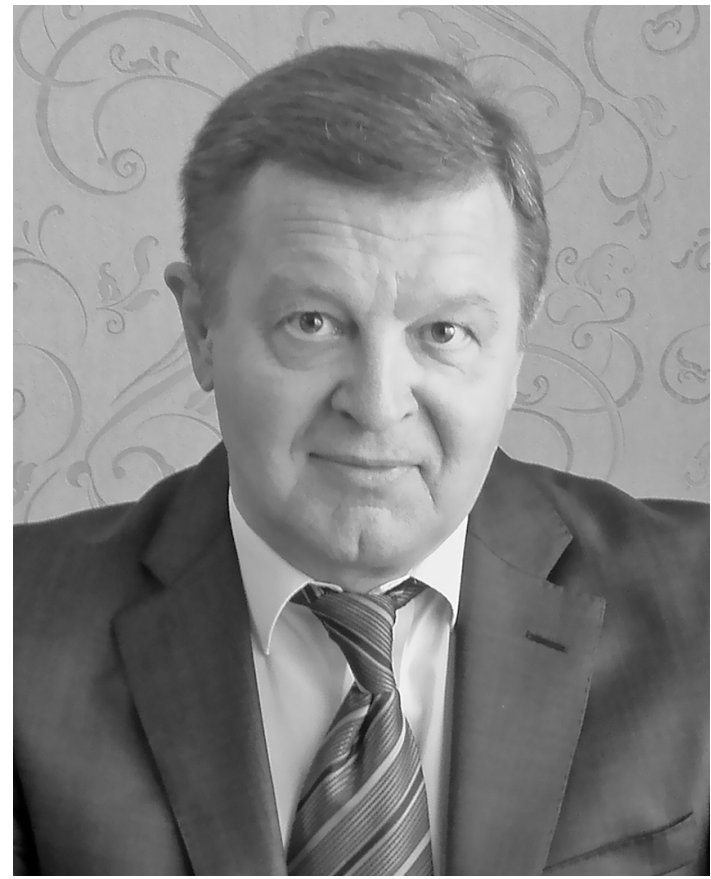

\title{
ОЛЕКСАНДР АНДРІЙОВИЧ БОЙЧУК (до 70-річчя від дня народження)
}

30 червня виповнилося 70 років знаному науковцю, члену-кореспонденту НАН України, лауреату Державної премії України в галузі науки і техніки Олександру Андрійовичу Бойчуку.

Народився Олександр Андрійович в місті Кіровограді (нині - Кропивницький). У 1967 році закінчив зі срібною медаллю Кіровоградську середню школу № 11 та вступив до Київського державного університету імені Тараса Шевченка на механіко-математичний факультет. З 1974 року навчався в аспірантурі Інституту математики НАН України, після закінчення якої захистив у 1978 році кандидатську дисертацію, а у 1992 році докторську. 31994 року працює в Інституті математики НАН України на посаді завідувача лабораторії крайових задач теорії диференціальних рівнянь. У 1997 році йому було присвоєно вчене звання професора зі спеціальності „диференціальні рівняння”.

О. А. Бойчук - відомий спеціаліст з теорії резонансних крайових задач із нормальнорозв'язним оператором у лінійній частині, що діє в гільбертовому або банаховому просторі. Характерною особливістю таких задач $є$ те, що в них кількість крайових умов не збігається 3 кількістю невідомих, а отже, це найбільш складні та малодосліджені недовизначені та перевизначені задачі. Олександр Андрійович уперше визначив умови розв'язності широкого класу нелінійних крайових задач для систем звичайних диференціальних та різницевих рівнянь, рівнянь із загаювальним аргументом, рівнянь 3 імпульсною дією, інтегро-диференціальних рівнянь, сингулярно збурених рівнянь. Для дослідження таких задач було запропоновано та ши- 
роко використано апарат узагальнено-обернених операторів, що дозволило суттєво просунути вперед якісну теорію крайових задач для таких систем. Уперше отримано низку оригінальних результатів, що стосуються крайових задач з умовами на нескінченності. Знайдено критерії існування обмежених на всій осі розв'язків лінійних та нелінійних систем звичайних диференціальних та різницевих рівнянь у припущенні експоненціальної дихотомії лінеаризованої однорідної системи на півосях, запропоновано алгоритми їхньої побудови. Отримано умови біфуркації та розгалудження розв'язків таких задач. Ці дослідження розвивають відомі результати Київської математичної школи з теорії нелінійних коливань, яка започаткована всесвітньо відомими вченими М. М. Криловим та М. М. Боголюбовим.

Ювіляр є автором понад 160 наукових праць та 5 монографій. Спільна з його науковим вчителем та колегою академіком А. М. Самойленком монографія видана англійською мовою в Нiдерландах і США (2004 р.) та витримала друге видання у видавництві De Gruyter, Berlin/Boston (2016 р.). У Словаччині словацькою мовою видано його підручник з теорії крайових задач для студентів університетів.

Наукові результати О. А. Бойчука доповідались автором на представницьких міжнародних конференціях в Австрії, Бельгії, Болгарії, Великій Британії, Греції, Ізраїлі, Іспанії, Латвії, Німеччині, Польщі, Румунії, Словаччині, Туреччині, Угорщині, Чехії та більшості країн СНД, де він був членом організаційних комітетів та запрошеним лектором.

Олександр Андрійович є лауреатом престижної премії НАН України імені Ю. Митропольського (2013р.), премії НАН України імені М. Г. Крейна (2020р.). Отримував гранти НАТО (Science Fellowships Programme 2002-2003), Словацької та Чеської грантових агенцій (20032010 рр.), Українського державного фонду фундаментальних досліджень (1995-2020рр.) та Соросівських фундацій.

Протягом останніх двадцяти років О. А. Бойчук за сумісництвом плідно працює професором кафедри інтегральних та диференціальних рівнянь Київського національного університету імені Тараса Шевченка, а також професором-дослідником (2002-2010 рр.) Університету міста Жиліна (Словаччина). Під його науковим керівництвом захищено чотири докторських та тринадцять кандидатських дисертацій, в тому числі Ph. D. дисертація в Словаччині. Тривалий час він працює у спеціалізованій раді з захисту докторських дисертацій в Інституті математики НАНУ України та при Київському національному університеті імені Тараса Шевченка, $є$ членом редакційної колегії „Українського математичного журналу”, заступником головного редактора журналу „Нелінійні коливання”, членом редакційної колегії „Буковинського математичного журналу".

Олександр Андрійович сповнений творчих задумів та енергії для їхньої реалізації. Тож, вітаючи його з ювілеєм, побажаємо йому міцного здоров'я та подальшого активного творчого життя в ім'я майбутнього Держави та народу України.

А. М. Самойленко, І. Т. Кігурадзе, І. О. Луковський, В. Л. Макаров, М. О. Перестюк, О. А. Бурилко, Й. Діблік, В. П. Журавльов, М. Медведь, I. О. Парасюк, О. О. Покутний, В. І. Ткаченко, С. М. Чуйко, М. Фечкан 